International Journal of Multi Disipline Science (IJ-MDS)

e-ISSN: 2615-1707 DOI: http://dx.doi.org/10.26737/ij-mds.v1i1.415

International Journal of Multi Disipline Science (IJ-MDS) is licensed under a Creative Commons Attribution-NonCommercial 4.0 International License.

\title{
Hypermedia-Based E-Book
}

\author{
Basuki wibawa $^{1}$, Bintang Petrus Sitepu ${ }^{2}$, Awaludin $^{3}$ \\ State University Jakarta, (UNJ) ${ }^{1}$, State University Jakarta, (UNJ) ${ }^{2}$, Halu Oleo University ${ }^{3}$ \\ Awu_fan@ymail.com
}

\author{
Keywords : \\ E-Book, Hypermedia, \\ Learning, cognitive, behavior, \\ constructivist, system.
}

\begin{abstract}
E-book is a digital form of printed book which includes digital information in the form of text, image, audio and video. Hypermedia-based e-book is a digital book with text, image, audio, video and animation where these multimedia components are connected. Thus it enables someone to access information provided from different places quickly. In order to develop hypermedia-based Ebook, some learning theories can be taken into consideration such as behaviorist theory, cognitive theory, constructivist theory and system learning approach. The advantages of hypermedia-based e-book are (1) enabling students to work on assignment individually or in group, (2) monitoring learning progress, (3) attractive size and composition, (4) the content can be customized to suit the learner's context, (5) learners can be active in constructing the content, (6) mental involvement and higher-order thinking process development, (7)the content of E-book is relevant with the learner's prior knowledge, (8) the content enables the learners to work together to comprehend the information, (9) teachers can be supervisors, (10) the questions are challenging and realistic for learners, (11) learners can interact with Ebook. Besides, E-book also possesses some disadvantages such as (1) special skills to make and design hypermediabased E-book, (2) special tools needed to access E-book, (3) for inexperienced user, accessing E-book can be quite difficult.
\end{abstract}

\section{INTRODUCTION}

International Society Technology for Education emphasizes that in 2016 the use of technology in education has reached the phase of technology transformation in learning. This suggests that in the future, educational practices cannot be separated from technology. In learning, teachers design their lesson using technology. The use of digital technology in learning is expected to help learners develop and construct knowledge and skills. One of the usages of digital technology is using electronic book as learning source. The use of electronic book (E- book) in education cannot be avoided. This is due to the effect of technology and science development. The use of e-book in learning is more efficient and effective than conventional book. E-book is portable, light, easy access through computer or hand-phone, more dynamic, unbreakable, alterable font size, easy information 
seeking, using navigation system, and connecting one text with other texts. E-book usage in learning also enables learners to interact with e-book, learning information suited with the learners" level, measure the level their own knowledge, absorb the information or concept easily in the form of text, image, video, audio and animation, control the content, and store information for long period.

Considering the benefits of digital technology or e-book in learning, e-book is needed to be designed properly to be best used in facilitating the learners to reach the expected competence in learning. This paper will elaborate the theory on hypermedia-based e-book, learning theory perspective on hypermedia-based E-book and the advantages of hypermedia-based E-book in learning. The questions to be answered are (1) what is hypermedia-based E-book?, (2) what are the advantages and disadvantages of hypermedia-based E-book? (3) How is conceptual model of hypermedia-based Ebook constructed?

\section{HYPERMEDIA-BASED E-BOOK THEORIES}

\section{Definition of E-book}

Electronic book (E-book) is a book in digital form which includes digital information in text, image, audio and video. According to Armstrong et al (as cited in Embong et al.,

2012), E-book is every electronic text regardless the size and composition (digital object) in electronic form in which every part is handled or accessed through a deskbound with a screen. In regards to the size, an e-book can contain long text, several images and alterable font size. Meanwhile, the composition of an e-book can be a text, or combination of text, image and audio, video and animation. Published journal is not categorized as an e-book because a journal must be published regularly.

Vassiliou and Rowley divide e-book's definition into two parts, (1) focus on the content and (2) focus on the function. E-book is a digital object in the form of text and other contents presented as an integration of the concept of a book presented electronically. E-book has some functions such as to search and cross references, hypertext links, bookmarks, multimedia object and an interactive tool.

Moreover, Onder (as cited Yalman) defined e-book as the digital form of a printed book, or one of complete printed digital books and can be accessed and viewed via portable devices such as computer or specifically-designed software for e-book readers.

According to Ching, Poon and McNaught, "e-books are electronic versions of books that are delivered to consumers in digital formats".

A similar definition is given by Figueireudo and Bidarra (2015), e-book is an electronic book in simpler format such as a text in PDF.

Based on the definitions of e-book from some experts above, it can be concluded that e-book is a digital form of a book which integrates several multimedia components such as texts, images, audio, video and can be accessed through electronic devices such as hand-phone or computer with a specified software installed in it.

E-book can be in the form of texts, audio, video, animation and combination of multimedia mentioned. E-book designed from the combination of several media inside is then called hypermedia-based ebook.

\section{The definition of hypermedia}

According to Robyler and Doering (2010), hypermedia is linked media or interactive media. In other words, hypermedia links several media such as text, image, audio and video. Bush (as cited in Robyler and Doering, 2010) defined hypermedia as a machine which enables people to access 
information quickly from different places. Moreover, Robyler and doering (idem) argued that hypermedia system stores information in the form of linked multimedia.

Both definitions explained that hypermedia is interrelation between multimedia stored in different places where each component is linked to one another. This is in line with Mishra and Sharma who stated hypermedia is the linking of multimedia documents. According to Vaughan (2011), hypermedia is structured and linked multimedia that enables users to navigate. This definition suggests that hypermedia users can move and control hypermedia as desired.

Meanwhile multimedia is a combination of text, graphics, arts, sound, animation and video sent to computer or other electronic devices. This definition emphasizes that interactive multimedia is hypermedia because a user can navigate it.

Hypermedia is software customized as the use of hypertext environment for non- sequential access to data. Non-sequential access data includes text, audio and visual information.

Based on the definitions above, hypermedia is a linking of multimedia components such as text, graphic, arts, sound, animation and video enabling someone to access information stored from different places quickly.

\section{The Definition of Hypermedia-based E-book}

Hypermedia-based e-book is a digital form of a book in which combines several multimedia components such as texts, images, audio and video as well as animation. These multimedia components are linked and can be viewed and accessed through electronic devices such as handphones or computers with specified software installed. The information in hypermedia connects one another and is stored in different places.

Hypermedia components such as texts, audio, video and animation are used as sources of information which enable users to get meaning or message from an e-book. A text in the form of letters is arranged into a meaningful word or a sentence. Audio is one of media including anything that anyone can hear for example sound, music or mechanical sound (Smaldino et.al., p. 479). Animation is a technique by manipulating images and put them into a sequence of moving images (Smaldino et al., 479)

Hypermedia-based e-book enables the users to navigate and search information stored in e-books as desired. As Sharon et al stated that navigation system of e-books enables a user to move freely inside the hypermedia screen through the press of a button or by choosing menu provided on screen.

Hypermedia-based e-book can be accessed through computers or other portable devices with a certain application installed. This is to maximize hypermedia e-book usage as source of learning.

\section{LEANING, E-BOOK AND HYPERMEDIA}

\section{Hypermedia-based e-book from behaviorist theory perspective.}

Learning in behaviorist theory focuses on observable behavior changes. Learning occurs when a response to a stimulus is reinforced. This learning theory was developed by Thorndike, Pavlov and Skinner. The emphasis is on the behavior change of learners that can be observed through the principle of "stimulus-response". According to Schunk (2012), learning is a process where association formed by stimulus and response. Furthermore, Smith and Ragan explained that behaviorism theorist conducted studies on human observable activities. Learning occurs when learners respond appropriately toward stimulus given.

Learning is the result of behavior formation caused by stimulus and response. The stimulus and response becomes stronger or intense if the frequency of reinforcement given is equally strong. Behavior transformation becomes faster if there is a model. The model makes it possible for learners to observe and build the awareness to learn independently.

To strengthen the relationship between stimulus and response, several ways can be done through the use of e-book. E-book can be designed specifically for learners which includes tasks with the hope that attitude can be transformed. E-book with hypermedia properties inside is a source of learning that assists learners in learning. E- book and hypermedia as learning sources provide all sort of information for learners to build their knowledge and skills. E-books should be designed with learners in mind. It 
means that e-book should be able to assist learners develop concepts through exercises. Thus, learning outcomes can be observed.

The characteristics of hypermedia-based e-book from behaviorist theory are (1)hypermedia e-book has both individual and group exercise built in it, (2) hypermedia has learning test, (3) through e-book, learners can monitor their learning outcomes, (4) the size and composition of e-books are attractive, (5) there is reinforcement in e-book if learners can do the exercise correctly, (6) there are procedures on how to finish the exercise such as graphic drawing etc.

\section{Hypermedia-based e-book from cognitive learning theory perspective}

According to Morrison et al (2013), cognitive learning theory emphasizes on the process of thinking, information processing, retaining and discounting information, obtaining and using language in communication. Moreover, Shcuell (as cited in Smith and Ragan,

2005) stated that five effects of cognitive psychology in learning are (1) learning is an activity, (2)learning promotes higher-order thinking process in learning, (3) the role of prior knowledge in learning is necessary, (4)knowledge is organized in memory and (5) learning involves the analysis of learning task and performances.

Based on the two points of view above, it can be concluded that learning is a mental activity such as think, understand, analyze, create, plan, problem-solve with the help of organized prior knowledge in learner"s memory. Learning will reach an optimal outcome if the task given is appropriate with learners"e cognitive development and internal character traits.

Januszweski and Molenda stated that in cognitive learning theory, learners utilize their memory and thinking process to produce strategies such as to keep and manipulate mental representation and ideas. Learning in cognitive point of view is the use of memory in code processing, storing and recalling information. In learning, new information given to learners should be relevant with the previous information or learners characteristics. Therefore, learners can easily use the information in task completion or performance development.

Moreover, Piaget (as cited in Santrock) argued that children ${ }^{\text {ee }}$ cognitive processes information through scheme, actions or mental representation to organize knowledge. In the early age, it is called attitude scheming; simple attitude structures on object such as sucking, seeking, grasping. Based on the explanation above, in order for learning to occur optimally or knowledge added, a teacher ought to be able to design problem schemata which is appropriate with children mental development.

Learning from cognitive theory perspective is viewed as obtaining information based on surrounding environment and appropriate mental development to be used to complete a task. For optimum and longer information retention, teachers should design specific learning media.

Hypermedia-based e-book as one of learning sources plays an important role to build learners ${ }^{\text {ee }}$ new knowledge. Through e-books, learners can learn all concepts, principles as well as procedures of a particular field of study. E-book that facilitates learners ${ }^{\text {ee }}$ thinking ability is an e-book which gives learners opportunity to explore, build conjecture, facilitate learning style and construct knowledge.

The characteristics of hypermedia-based e-book from cognitive theory point of view are (1) e-book content relates with learners" social context, (2) learners participate actively in constructing knowledge from the e-book, (3) through e-book, learners involve mentally and develop higher-order thinking process, (4) e-book content is relevant with learners"e prior knowledge, (5) there are tasks for learners to complete.

\section{Hypermedia-based e-book from constructivist theory perspective}

Slavin stated that constructivist theory viewed learners as they who always try to match between old information and new information and revise irrelevant information. The emphasis is on the learnerse 
active participation. Therefore, constructivism strategy is known as student-centered instruction. The history of constructivist theory development was from Piaget and Vigotsky where both theorists emphasized that the cognitive change occurs when previous concept was disequilibrium in light of new information.

According to Slavin, there are four principles of Vygotsky arguments in relation to constructivist learning theory. Firstly, social learning is where children learn through interaction with adults with high capability. This way helps not only with learning outcomes but also children "es thinking process. Secondly, zone of proximal development (ZPD) is where learners learn concepts well if they are learning within their ZPD. Learners learn within their ZPD when they are involved with difficult task and in need of assistance from their peers or adults (teachers). Vygotsky defined ZPD as an interval between actual development (determined by independent problem solving) and potential development (determined by assisted problem solving by adults or more capable peers). Thirdly, cognitive apprenticeship is a process where learners gradually reach the skill through interaction with experts. Someone who works closely with an expert by giving example, feedback to someone novice will gradually promote to the professional norm and attitude.

Fourthly, Vigotsky emphasized on the importance of scaffolding and mediated learning for learners by giving complex, difficult and realistic tasks. Then, learners are given a little help to complete some of the tasks. This principle is used to support the project, simulation, and also authentic tasks in class.

Learning according to constructivist theory is a process to construct new knowledge based on prior knowledge by interacting with environment or someone with higher knowledge to reach the optimum knowledge. E-book is a tool at learners"e disposal to construct new knowledge. Therefore, ebook based on constructivist theory is e-book that emphasizes on the collaborative/group work, development of learners potential and experts involvement in the use of hypermedia-based e-book as learning source. In this case, e-book content includes tasks specifically designed for learners. The tasks may vary from easy, medium to difficult category and realistic. The characteristics of Hypermedia- based e-book according to constructivism theory are (1)e-book content enables learners to work collaboratively in understanding the information, (2) the role of teachers is as supervisors, (3) the tasks are challenging and realistic, (4)e-book can be linked with previous material.

\section{Hypermedia-based e-book from system approaches perspective}

From system approaches point of view, learning will be efficient when it is supported with sound learning design. Learning systems consist of objective, activity, and evaluation (Robyler and Doering, , 2010,37)

Further, Dick and Carey argue that learning process can be viewed as the system with purpose to bring about the learning. The system components include learners, instructors, instructional materials and instructional learning. All of them are integrated to reach the learning objective. This perspective is the foundation underlying the use of system approaches in designing, developing and implementing and evaluating. This view is also influenced by Robert Gagne in his book „The condition of Learningee published in 1996.

„The Condition of Learninge views learning as cognitive transformation-process by assuming that human attitude is complex and is controlled by inner mental process rather than external and environment. Learning is viewed as organizing and storing information, examples, experiences, and activities which guide, support and add learners"e inner mental process. Learning exists when learners are able to combine new information and prior knowledge in their memory and form new capabilities (Dick and Carey, p 3). According to Gagne, capabilities are the abilities, knowledge and attitude that human obtain (Gredler, 2011, p 10).

E-book in system approaches is viewed as learning material which used by learners to achieve higher competency. Therefore, e-book should be designed with learners in mind in order to facilitate learning. E-book should be developed through several stages of learning such as designing, developing, implementing, and evaluating. The characteristics of e-book in system approaches are (1) e-book is 
designed with learners in mind, (2) e-book should be appropriate with the learning objectives, (3) e-book should be integrated with various learning multimedia, (4) e-book includes exercise and formative test, (5) the content should be appropriate with the learning objectives, (6) the materials are structured from objectives to learning strategies.

\section{THE ADVANTAGES AND DISADVANTAGES OF HYPERMEDIA-BASED E-BOOK}

The advantages of hypermedia-based e-book in learning are;

1) enabling the learners to do either individual or group exercise

2) through e-book, learners could monitor learning progress

3) interesting size and composition for learning

4) e-book content can be constructed to suit learners social environment

5) learners participate actively in constructing knowledge in e-book

6) through e-book, learners participate mentally and develop higher-order thinking process

7) e-book content is relevant with learners"e prior knowledge

8) e-book content enables learners to work cooperatively in understanding information

9) teachers act as supervisors

10) learners can interact with e-book

The disadvantages of hypermedia-based e-book are (1) it requires special set of skills to make or design hypermedia-based e-book; (2) it requires special device to access e-book; (3) Learners who are unfamiliar with such technology will find problems.

\section{THEORETICAL MODEL OF HYPERMEDIA-BASED E-BOOK}

Learning is the change on learners" behavior. The changes include knowledge, abilities and attitude within a set period of time of experience. The better change on learners "e behavior occurs due to strong relationship of stimulus and response. Besides, the change is also affected by planned action such reinforcement. As a result, association between stimulus and response becomes stronger. The more reinforcement is given, the more well behaved the learners become. The effect of stimulus and response in education is when teachers give exercise to learners (stimulus), they do them (response). Therefore, the change in the learners ${ }^{\text {ee }}$ behavior should be observed or evaluated. This can be done by giving test or questions.

From cognitive psychology point of view, behavior change goes through thinking process. Learning is mental activity. Mental activity here means think, receive, process, and use of information. In addition, mental activity also includes understand, explain, reason, create, plan, mention, analyze, problemsolve. Someone can process information if the information received is relevant with the previous information.

Learners can construct knowledge received if information is relevant with the previous information. Therefore, learners will maximize in their learning if learners when constructing knowledge receive help or support from the peers or teachers.

Learning activity as explained above can be maximized if there is a teacher who can teach learners. In this context, a learning concept is needed to accommodate learning types mentioned above.

Learning is a collection of activities that is planned well to create interaction between learners and learning materials in order to achieve learning objective. Learning components are learners, teachers and learning materials which every component has its own role and together work harmoniously to achieve learning objective. Based on that perspective, therefore learning is considered as a system. Viewing learning as a system then creating a system approaches to problem solving is necessary. It means that to improve or achieve learning outcome, many factors should be taken into consideration such as learners factor, teachers, learning source (infrastructure and learning materials). 
To achieve optimum learning objective, learning must be designed well. One of the aspects that should be designed and developed is learning material. In the process of designing learning material, the designer will have to identify, analyze several aspects in learning such as learning objectives, learners ${ }^{\text {ee }}$ characteristics, and also developing evaluation items, constructing teaching strategies including methods, media and time allocation.

Instructional material is learning source specifically designed by teachers under learning approach. Instructional material in class can be used to facilitate learners during learning. Instructional material should enable learners in constructing knowledge and ability in regard with learners e internal character traits.

In designing learning material, technology should be integrated to enable easy learning. For example computer can be integrated in learning with other multimedia components. Multimedia components includes text, graphic, image, sound video and animation. Multimedia components are connected using hyperlink or link.

Learning material designed to improve learning outcome is learning material hypermedia-based ebook. The use of hypermedia-based e-book in learning is because (1) learners can obtain learning information from various media, (2) technology can facilitate learners to achieve learning objective, (3) hypermedia-based e-book can be accessed by learners either via computer or hand-phone, (4) as the development of technology, the use of computer in learning becomes a necessity. According to Robyler and Doering, e-book is a valuable learning source for learners and teachers because it is more flexible than text-books.

The use of hypermedia-based e-book in integral calculus class is expected to promote students ${ }^{\text {ec }}$ active participation in constructing concept, principle in relation to integral calculus. Then students are able to apply the concept and principle to solve problems. Moreover, students are expected to arrange mathematics models of a problem given and understand the procedures to solve an integral calculus problem.

Hypermedia-based e-book can be arranged interactively by connecting various components of multimedia such as texts, sound, images, video and animation. When a text is linked with the other texts, it is expected to give detail concept for students to understand. When a text is linked with an image, the concept is visualized and clarified. When the text is linked with sound then students can listen to the explanation of concept or principle being studied. Next, when the concept is presented via image and sound, it enables the students to learn easily. When e-book is linked with animation, students can watch a simulation in constructing a concept.

Various information channel used in e-book enables students to retain information given. Using different ways in presenting information in hypermedia-based e-book can accommodate different learning styles such as visual, auditory and kinesthetic learning style. The concept of hypermedia in ebook is similar with the concept of technology in education which has a purpose to facilitate learners to achieve learning objectives. The competences expected after learning calculus will be achieved using hypermedia-based e-book.

The use of e-book in learning has several advantages such as (1) easy retrieval and distribution, (2) simple storing process, (3) alterable font size, (4) text in multimedia form, (5) readable from different device, (6) large size e-book can be stored in one device.

Moreover, according to Kaplan, the advantages of e-book are (1) reader can search and find an appropriate word or subject fast, (2) e-book can be updated frequently, (3) e-book can be accessed from different devices, (4) many computer applications can be used to read e-books, (5) readers can enlarge the font and image easily, (6) e-book content can include video, audio, quiz and animation for interactive purpose, (7)e-book can minimize the space needed by a library. 
The use of multimedia and hypermedia has given positive effects on learning such as (1) Robyler found that the advantage of multimedia and hypermedia in class is that learners can process information from different channel, (2) Mayer found that learners who get the explanation via visual and verbal are more creative in problem solving, (3) Mater found that multimedia and hypermedia systems affect learners with spatial ability and low schemata, (4) Mayer and Moren, Moreno and Moreno found that learners who paid attention would have mastered and retained learning material when they were exposed to image and spoken words altogether, compared to written words exposure, (5)Swan and Meskill, Dillon and Gabbard concluded that a) hypermedia has a primary advantage that is quick-search from various source of information, b) improve function of students ${ }^{\text {e }}$ control. Hypermedia is more beneficial for high achiever learners while low achiever learner struggle with hypermedia, c) hypermedia can accommodate different learning styles. Learners with high intelligence can explore hypermedia further (Robyler and Doering, 2010, p. 172).

A study by Doty, Popplewell and Byers revealed that students ${ }^{\text {ee }}$ ability to answer questions is higher when reading stories in storyboard electronic format than reading stories from a traditional storybook. In addition, Grimshaw found a significant improvement in enjoyment and mastery after using electronic storybook.

Hypermedia-based e-book enables students to study the learning material independently, accommodate learners ${ }^{\text {ee }}$ characteristics and learning styles, involve learners to construct graphic. When a text is connected with other texts, learners will be presented with the explanation of a concept or principle being studied. The model of conceptual development of hypermedia-based e-book can be seen below:

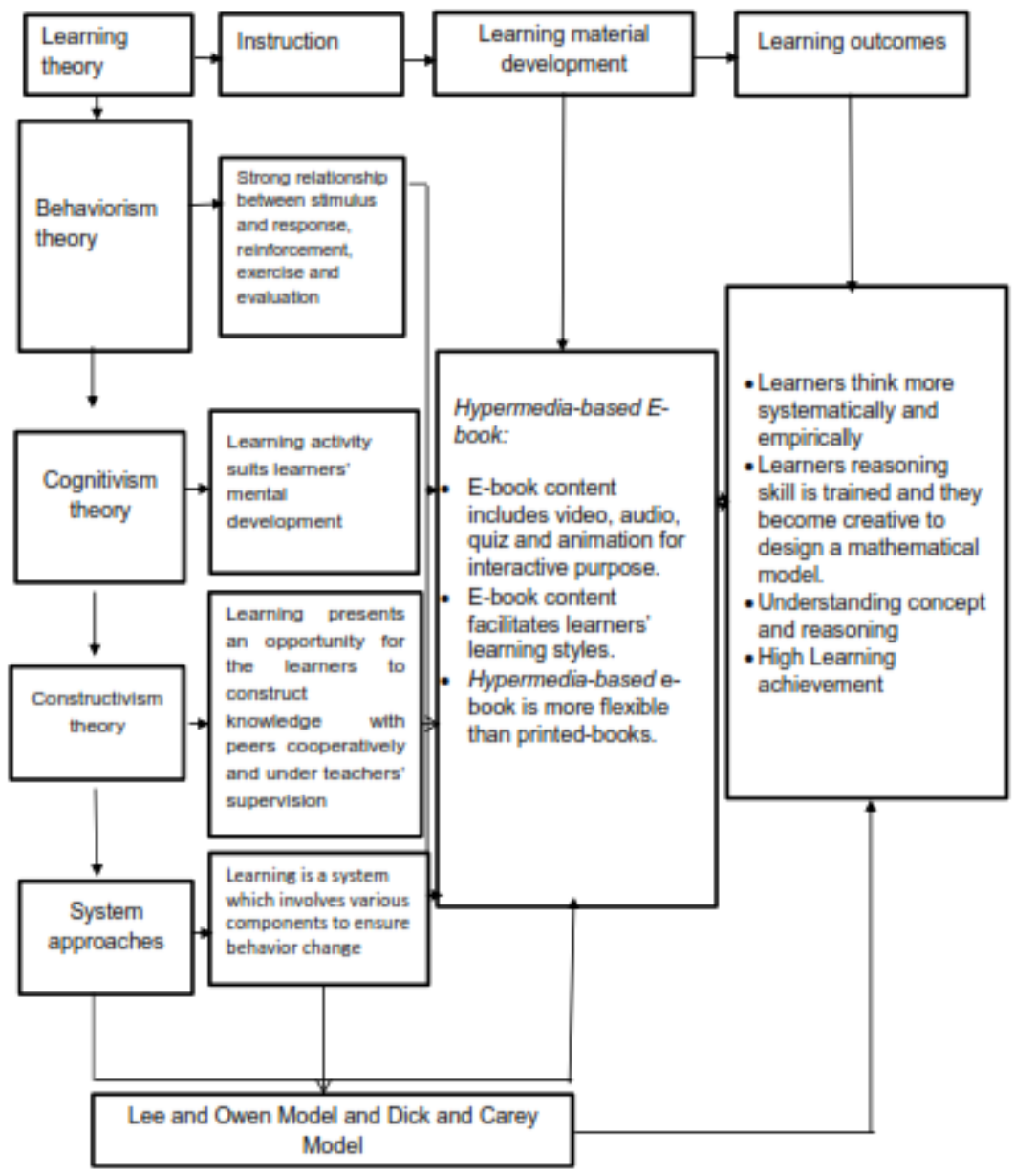

Fig 1. Conceptual framework of hypermedia-based e-book 


\section{METHOD}

In this research, we use literature review method which collect some resources from books, articles and scientific journals. This research provides information linked in hypermedia based E-book to give reader basic knowledge about the topic.

\section{CONCLUSION AND SUGGESTION}

The conclusions in this article are as follows

a. Hypermedia-based e-book is a digital form of a book in which combines several multimedia components such as texts, images, audio and video as well as animation. These multimedia components are linked and can be viewed and accessed through electronic devices such as handphones or computers with specified software installed. The information in hypermedia connects one another and is stored in different places.

b. The advantages of hypermedia-based e-book in learning are; (1) enabling the learners to do either individual or group exercise, (2) through e-book, learners could monitor learning progress, (3) interesting size and composition for learning, (4) e-book content can be constructed to suit learners social environment, (5) learners participate actively in constructing knowledge in e-book, (6) through e-book, learners participate mentally and develop higher-order thinking process, (7) e-book content is relevant with learners" ${ }^{\text {ec }}$ prior knowledge, (8) e-book content enables learners to work cooperatively in understanding information, (9) teachers act as supervisors, (10) learners can interact with e-book. The disadvantages of hypermedia-based e-book are; (1) it requires special set of skills to make or design hypermedia-based e-book (2) it requires special device to access e-book, (3) Learners who are unfamiliar with such technology will find problems.

\section{REFERENCES}

Ching, Hsianghoo Steve, Poon, Paul W. T.,and McNaught, Carmel, (n.d.), E-Learning and Digital Publishing, ed. (Netherlands: Springer), h.114.

Embong, Abd Mutalib et al., (2012). "E-Book as Textbooks in the classroom, "Procedia: Social and Behavioral Sciences, Elsevier 2012, p. 1802-1803.

Figueiredo, Mauro and Bidarra, José, (2015), "The development of a Gamebook for education, 6th International Conference on Software Development and Technologies for Enhancing Accessibility and Fighting Infoexclusion," Procedia: Computer Sciencel, Elseveir, p. 325.

Kefi, Hajer, (2015), Information Technology Ethics: Concepts and Pratics in the world, British: Cambridge Scholars Publishing), p. 118.

$\mathrm{Lu}$, Joan and $\mathrm{Xu}$, Qiang, (2017), Examining Information Retrievel and image Processing Paradigms in Multidiciplinary Contexts (Penssilvenia: IGI Global) p. 151.

Mishra, Sanjaya and Sharma, Ramesh C., (2005), Interactive Multimedia in education and Training Hersey, Idea Group Publishing,), p. 5.

Morrison, Gary R. et al., (2013), Designing Effective Instruction,(New York, Wiley, p. 357.

Roblyer, Margaret D. and Doering, Aaron H., (2010), Integrating Educational Technology into Teaching Boston, Pearson, p. 170.

Schunk, Dale H. (2012), Leraning Theories, an Educational Perspective, Boston, Person, p. 114. Slavin, Robert E. (2006), Educational Psychology, Theory and Practice, Boston, Pearson, p. 243.

Smaldino, Sharon E., Lowther, Deborah L., and Russel, James D., (2012), Instructional Tecnology and Media For Learning,Person Education, Inc, , p.485.

Smith, Patricia L. \& Ragan, Tillman J., (2015), Instructional Design, John Wiley and Sons, Inc, p. 26.

Vaughan, Tay, (2011), Multimedia: Making it Work, New York, McGraw Hill, p. 1. 